e-journal Keperawatan (eKp) Volume 7 Nomor 1, 11 Februari 2019

\title{
HUBUNGAN PENGGUNAAN KONTRASEPSI PIL KB KOMBINASI DENGAN PERUBAHAN SIKLUS MENSTRUASI DI PUSKESMAS SONDER KECAMATAN SONDER KABUPATEN MINAHASA
}

\author{
Sefti Rompas \\ Michael Karundeng \\ Program Studi Ilmu Keperawatan Fakultas Kedokteran \\ Universitas Sam Ratulangi \\ Email: seftirompas@yahoo.com
}

\begin{abstract}
Menstruastion is change in body fisiology in human body with view circumstances and being influence by reproductive hormones or is being said blood flowing out, mucus and debrissel from uterine mucosa accompanied by release endometrium periodically and cycle with beginning in 14 day after ovulation. Menstrual periodic is a relevant indicator of reproductive health and changes in the menstrual cycle can effect a woman quality of life.And then, abnormal menstrual cycle can interfere woman reproductive health.As for the factors that influence changes in the menstrual cycle not only biological factors and social environmental factors but also influence by contraception. The choice of the contraception cannot be generalized because it depends on the character and deedsof individual. Pill end injection contraception is hormonal contraception. The purpose of research is to find out is there are relationship between use of contraception pil with the change on menstruation cycle. The design is quantitative Dedskriptif with cross sectional approach. The sample is taken with total sampling technic, with total sample is 40 respondents. The result statisyic chi square obtained $p=0,001$. The Conclusion there is relationship between use contraception combinastion pil with change in menstruastion cycle at puskesmas sonder county minshasa.
\end{abstract}

Keywords : combination Pil, change menstruastion cycle.

Abstrak : Menstruasi atau haid adalah perubahan fisiologis dalam tubuh wanita yang secara berkala terjadi dan dipengaruhi oleh hormon reproduksi, atau disebut juga pengeluaran darah, mukus, dan debrissel dari mukosa uterus disertai pelepasan (deskuamasi) endometrium secara periodik dan siklik, yang dimulai sekitar 14 hari setelah ovulasi. Siklus menstruasi dianggap sebagai indijator yang relevan dari kesehatan reproduksi, dan perubahan pada siklus menstruasi dapat mempengaruhi kualitas hidup wanita. Dengan demikian siklus menstruasi yang tidak normal dapat mengganggu kesehatan reproduksi wanita. Adapun faktor yang mempengaruhi perubahan pada siklus menstruasi tidak hanya faktor biologis dan faktor lingkungan sosial tetapi juga dipengaruhi oleh alat kontrasepsi. Pemilihan kontrasepsi tidak dapat disamaratakan karena tergantung karakter dan keperluan individu tersebut. KB suntik dan pil KB merupakan kontrasepsi hormonal Tujuan penelitian ini untuk mengetahui Apakah ada hubungan penggunaan kontrasepsi pil Kombinasi dengan perubahan siklus menstruasi di Puskesmas Sonder. Desain penelitian ini menggunakan jenis penelitian deskriptif kuantitatif dengan pendekatan cross sectional. Sampel diambil dengan Teknik pengambilan total sampling dengan jumlah sampel sebanyak 40 responden. Hasil penelitian statstic uji Chi-Square didapatkan $p=0.001$. Kesimpulan terdapat hubungan antara penggunaan kontrasepsi pil KB dengan perubahan siklus menstruasi di Puskesmas Sonder.

Kata Kunci : Pil Kombinasi,Perubahan Siklus Menstruasi 


\section{PENDAHULUAN}

Menstruasi atau haid adalah perubahan fisiologis dalam tubuh wanita yang secara berkala terjadi dan dipengaruhi oleh hormon reproduksi, atau disebut juga pengeluaran darah, mukus, dan debrissel dari mukosa uterus disertai pelepasan (deskuamasi) endometrium secara periodik dan siklik, yang dimulai sekitar 14 hari setelah ovulasi (Dasharathy, 2012). Siklus menstruasi merupakan waktu sejak hari pertama menstruasi sampai datangnya menstruasi periode berikutnya. Siklus menstruasi pada wanita normalnya berkisar antara 21-35 hari dan hanya $10-15 \%$ yang memiliki siklus premenstruasi 28 hari dengan lama menstruasi 3-5 hari, ada yang 7-8 hari (Baziad, 2008).

Siklus menstruasi dianggap sebagai indikator yang relevan dari kesehatan reproduksi, dan perubahan pada siklus perdarahan dapat mempengaruhi kualitas hidup wanita (Nurlaila, 2015). Dengan demikian siklus menstruasi yang tidak normal dapat berpotensi menggangu kesehatan reproduksi wanita. Berdasarkan studi biopsikososial, faktor yang mempengaruhi siklus menstruasi tidak hanya faktor biologis yaitu gangguan hormonal dan gaya hidup seperti olahraga dan nutrisi, tetapi juga dipengaruhi oleh faktor lingkungan dan sosial seperti hubungan dengan teman, keluarga, rekan kerja maupun sekolah serta faktor psikologis termasuk kecemasan, depresi, dan stres. Keterlambatan usia menarke dan usia yang lebih muda juga merupakan faktor terjadinya siklus menstruasi yang tidak teratur (Sianipar, 2009).

$$
\text { Riset Kesehatan Dasar }
$$

(Rikesdas) tahun 2010, sebagian besar $68 \%$ perempuan di Indonesia berusia 10 59 tahun melaporkan haid teratur dan $13,7 \%$ mengalami masalah siklus haid yang tidak teratur dalam 1 tahun terakhir. Persentase tertinggi haid tidak teratur adalah Sulawesi Utara $(23,3 \%)$ dan terendah di Sulawesi Tenggara 8,7\%. Masalah haid tidak teratur sudah mulai banyak terjadi pada usia 45-49 tahun $17,4 \%$ dan 50-54 tahun $17,1 \%$ kemungkinan terkait dengan umur menopause. Adapun alasan yang dikemukakan perempuan 10-59 tahun yang mempunyai siklus menstruasi tidak teratur di karenakan stres dan banyak pikiran sebesar $5,1 \%$.

Menurut World Health Organization (WHO), tahun 2009 hampir 380 juta pasangan menjalankan keluarga berencana dan 65-75 juta diantaranya terutama di negeri berkembang menggunakan kontrasepsi hormonal yaitu pil KB. Akan tetapi 5\% dari jumlah tersebut penggunanya adalah tidak melakukan pengkonsumsian secara teratur sehingga beresiko terjadinya kehamilan.

Menstruasi atau haid adalah perdarahan secara periodik dan siklik dari uterus, disertai pelepasan (deskuamasi) endometrium. Proses terjadinya haid berlangsung dengan empat tahapan yaitu masa proliferasi, masa ovulasi, masa sekresi dan masa haid. Siklus haid normal dapat dipahami dengan mudah dengan membaginya menjadi tiga fase yaitu fase folikuler, saat ovulasi, dan fase luteal. Perubahan-perubahan kadar hormon sepanjang siklus haid disebabkan oleh mekanisme umpan balik (feedback) antara hormon steroid dan hormone gonadotropin.

Hasil pelayanan Peserta KB di Puskesmas Sonder dari januari sampai dengan bulan Maret 2018 mencapai 97 peserta. Pencapaian penggunaan kontrasepsi rata-rata perbulan diatas (50\%) dan apabila persentase pencapaian rata-rata ini dapat dipertahankan, maka sasaran pencapaian peserta KB Baru tahun 2018 akan tercapai. Dari pencapaian sebanyak 7 peserta KB Baru tersebut, peserta KB IUD mencapai 11 peserta, peserta KB Kondom 0 peserta peserta KB Implant mencapai 18 peserta, peserta KB Suntik mencapai 21 
peserta dan peserta KB PIL Kombinasi mencapai 40 peserta dimana berdasarkan hasil wawancara 10 diantaranya mengaku mengalami pendarahan bercak serta darah yang keluar saat haid sedikit sehingga lama haid menjadi panjang.

\section{METODE PENELITIAN}

Desain penelitian yang digunakan adalah menggunakan jenis penelitian deskriptif kuantitatif dengan pendekatan cross sectional. Dimana pengambilan variabel dependent (terikat) dan independent (bebas) dilakukan secara bersamaan. Populasi adalah wilayah generalisasi yang terdiri atas obyek/subyek yang mempunyai kualitas dan karakteristik tertentu yang ditetapkan oleh peneliti untuk dipelajari kemudian ditarik kesimpulan (Sugiyono, 2011). Populasi yang digunakan dalam penelitian ini adalah akseptor Pil KB Kombinasi di Puskesmas Sonder. Populasi dalam penelitian ini adalah 40 orang.

Sampel yang digunakan adalah total sampling. Ada 2 variabel yang digunakan, yakni variabel independen penggunaan kontrasepsi pil $\mathrm{KB}$ dan variabel dependen perubahan siklus menstruasi. Instrument dalam penelitian ini peneliti menggunakan kuesioner dengan hasil uji validitas diperoleh Alpha $>6$. Untuk menilai karakteristik responden yang terdiri dari umur, pekerjaan dan Pendidikan terakhir, cara menilai menggunakan kontrasepsi pil KB yakni dengan menggunakan lembar observasi, Monofasik diberi skor 2, trifasik diberi skor 1. Untuk menilai perubahan pada siklus menstruasi menggunakan lembar observasi dengan mengukur siklus menstruasi amenorea dan polimenorea.

Data yang terkumpul diolah dan di analisis dengan menggunakan Statistical Product and Service Solution (SPSS. Untuk mendapatkan data yang benar kemudian dilakukan pengumpulan data dan pengelolahan data (editing, coding, tabulating, claning). Analisa data dalam penelitian ini yaitu analisi univariat dan bivariat. Analisis univariat dilakukan terhadap variable penelitian untuk mrlihat tampilan distribusi frekuensi dan persentase disetiap variable.Analisis bivariat dilakukan untuk melihat hubungan antara variabel dengan menggunakan uji chi-square dengan tingkan kemaknaan $95 \%$ dan tingkat signifikan $(\alpha) ; \leq 0,05$. Hasil perhitungan menggunakan program komputer. Dalam melakukan peneltian memperhatikan masalah etika penelitian yang meliputi : lembar persetujian diberikan kepada responden yang memenuhi kriteria inklusi,jika subjek menolak peneliti tidak memaksa dan menghormati hak mereka (informed consen), untuk menjaga kerahasiaan,penelitili tidak akan mencantumkan nama tapi diberikan inisial (anonymity), untuk menjaga kerahasiaan informal responden dijami oleh peneliti dan hanya data-data tertentu yang akan dilaporkan sebagai hasil peneliti (confidentially)

\section{HASIL dan PEMBAHASAN}

1. Penggunaan Kontrasepsi Pil KB di Puskemas Sonder

Tabel 1. Distribusi Penggunaan Kontrasepsi Pil KB responden di Puskesmas Sonder

\begin{tabular}{|c|c|c|}
\hline $\begin{array}{l}\text { Penggunaan } \\
\text { Kontrasepsi Pil } \\
\text { KB }\end{array}$ & $\mathbf{n}$ & $\%$ \\
\hline Monofasik & 17 & 42.5 \\
\hline Trifasik & 23 & 57.5 \\
\hline Total & 40 & 100.0 \\
\hline
\end{tabular}

Distribusi penggunaan kontasepsi pil $\mathrm{KB}$ menunjukan bahwa penggunaan kontrasepsi pil KB terbanyak adalah trifasik yakni sebanyak 23 responden (57.5\%). Penggunaan pil oral terutama yang jenis oral kombinasi trifasik disebabkan jenis pil ini menurut beberapa responden lebih mudah pemakaiannya dan 


\section{e-journal Keperawatan (eKp) Volume 7 Nomor 1, 11 Februari 2019}

mudah diingat dari pada jenis lain. Selain itu informasi yang cukup baik telah diberikan oleh tenaga kesehatan, khususnya bidan desa setempat, sehingga pemahaman responden juga cukup baik mengenai jenis kontrasepsi ini. Pada pemakaian pil trifasik, kadang tidak ditemukan perdarahan lucut. Pada umumnya amenorea terjadi pada penggunaan pil dengan dosis gestagen yang tinggi atau pada penggunaan depo gestagen. Pemakaian kontrasepsi oral kombinasi dapat mempunyai efek samping terhadap perubahan siklus menstruasi, baik pemakaian kontrasepsi monofasik, bifasik maupun trifasik. Sehingga merupakan hal yang wajar jika resonden mengalami perubahan siklus menstruasi karena ketidaksesuaian dengan system hormon tubuh (Baziad, 2008).

Keuntungan utama pil adalah keefektifannya yang sangat tinggi apabila digunakan dengan tepat dan benar. Pil memenuhi unsur sederhana, mudah penggunaannya, tidak memerlukan intervensi medis, tidak memerlukan pemeriksaan dalam bagi pemakainya, tidak menggangu senggama. Penelitian tentang pil sudah cukup banyak sehingga pil diyakini melindungi wanita terhadap penyakit radang panggul. Hal ini disebabkan oleh beberapa mekanisme antara lain pil mengurangi jumlah darah menstruasi sehingga mengurangi medium kultur untuk beberapa jenis kuman. Pil juga menjadikan siklus haid lebih teratur mengurangi rasa sakit (dismenorea) dan menurunkan jumlah darah yang hilang sehingga mengurangi insidensi anemia (Siswosudarmo, 2007).

Cara penggunaan pil oral kombinasi yaitu dengan cara sebaiknya diminum setiap hari pada saat yang sama, dan bila lupa minum pil segera minum pil setelah di ingat pada hari yang sama. Karena pil oral kombinasi merupakan alat kontrasespi yang dapat memiliki efektifitas tinggi lebih dari 99\%, apabila digunakan secara benar dan konsisten karena pil akan dimetaboliser dalam 24 jam. Apabila akseptor lupa minum 1-2 pil maka dapt terjadi peningkatan hormone alamiah yang dapat mengakibatkan terjadinya pelepasan ovum. Efektifitas pil kombinasi juga dapat berkurang apabila tidak di minum dalam waktu yang sama. Hormon-hormon ini, yang diminum setiap hari bekerja untuk menghambat ovulasi, mengubah lapisan endometrium, dan menghalangi perjalanan sperma ke dalam uterus dengan mengentalkan mucus serviks. Pada sediaan monofasik, makin kecil dosis estrogen dan progesteron, makin sedikit pula darah yang keluar dan makin besar dosis estrogen dan progesteron, makin banyak pula darah yang keluar (Baziad, 2008).

Hasil penelitian ini sama dengan hasil penelitian yang dilakukan oleh Wahyuni (2013) yang menyatakan bahwa akseptor KB di Kelurahan Aur Kuning Wilayah Kerja Puskesmas Aur Birugo Tigo Baleh Kota Bukittinggi lebih banyak yang menggunakan kontrasepsi pil sebanyak 41 orang $(50,6 \%)$. Hasil penelitian Sanding (2014) menyatakan bahwa dari 2.898 istri pasangan usia subur di Puskesmas Modayag Kecamatan Modayag Kabupaten Bolaang Mongondow Timur lebih banyak yang menggunakan jenis kontrasepsi pil sebanyak 1.123 orang $(38,75 \%)$.

2. Perubahan Siklus Menstruasi di Puskesmas Sonder.

Tabel 2 Distribusi Perubahan siklus menstruasi responden di Puskesmas Sonder

\begin{tabular}{lcc}
\hline $\begin{array}{l}\text { Perubahan Siklus } \\
\text { Menstruasi }\end{array}$ & n & $\%$ \\
\hline Polimenorea & 21 & 52.5 \\
Aminorea & 19 & 47.5 \\
\hline Total & 40 & 100.0 \\
\hline Sumber : Data Premier & 2018 &
\end{tabular}

Distribusi perubahan siklus menstruasi menunjukan bahwa mayoritas responden mengalami perubahan siklus menstruasi polimenorea yakni sebanyak 21 
responden (52.5\%). Menurut Sarwono (2008) pengaruh kontrasepsi hormonal dapat menyebabkan perubahan terhadap sekresi steroid seks dan ovarium sehingga keluhan-keluhan yang timbul sebelum atau selama haid seperti nyeri haid (dismenorea), dan sindroma premenstrual (PMS), dan mastodini (nyeri payudara) dapat diobati dengan pemberian kontrasepsi hormonal. Seperti diketahui, bahwa haid yang normal terjadi akibat kadar progesteron yang turun, sedangkan pada penggunaan pil kombinasi, haid yang terjadi akibat turunnya kadar hormon sintetik.

Haid yang terjadi setelah penggunaan pil kombinasi atau pil sekuensial lebih tepat kalau dikatakan sebagai pseudo haid. Siklus haid adalah jarak antara hari pertama haid dengan hari haid berikutnya. Siklus haid normal ialah 15-45 hari. Panjang siklus haid yang dianggap rata-rata ialah 28 hari (Suryoprajogo, 2008). Hasil penelitian menunjukan bahwa mayoritas responden mengalami perubahan siklus menstruasi polimenorea yakni sebanyak 21 responden (52.5\%). Perubahan siklus menstruasi yang dialami oleh sebagian besar responden secara fisiologis menggambarkan organ reproduksi yang cenderung mengalami masalah. Hal ini dapat disebabkan oleh berbagai penyebab, seperti perubahan hormonal akibat penggunaan kontrasepsi hormonal atau stres, diet yang buruk serta aktifitas fisik yang berat. Pada umumnya menstruasi akan berlangsung setiap 28 hari selama +7 hari. Lama perdarahan sekitar 3-5 hari dan tidak terasa nyeri. Jumlah darah yang hilang sekitar 30-40 cc. Puncaknya hari kedua atau ketiga dengan jumlah pemakaian pembalut sekitar 2-3 buah (Manuaba, 2009).
3. Hubungan penggunaan kontrasepsi pil KB dengan perubahan siklus menstruasi di Puskesmas Sonder

Tabel 3. Hubungan Penggunaan Kontrasepsi Pil KB Kombinasi dengan perubahan Siklus Menstruasi di Puskesmas Sonder Kecamatan Sonder Kabupaten Minahasa

\begin{tabular}{lccccccc}
\hline \multirow{2}{*}{$\begin{array}{c}\text { Penggunaan } \\
\text { kontrasepsi } \\
\text { Pil KB }\end{array}$} & \multicolumn{5}{c}{ Perubahan siklus Menstruasi } & P \\
\cline { 2 - 6 } & Polimenorea & Aminorea & \multicolumn{2}{c}{ Total } & Value \\
\cline { 2 - 6 } & $\mathrm{n}$ & $\%$ & $\mathrm{n}$ & $\%$ & $\mathrm{n}$ & $\%$ & \\
\hline Monofasik & 14 & 35,0 & 3 & 7,5 & 17 & 42,5 & \\
Trifasik & 7 & 17,5 & 16 & 40,0 & 23 & 57,5 & 0,001 \\
\hline Total & 21 & 52,5 & 19 & 47,5 & 40 & 100 & \\
\hline Sumber : Data & Premier & 2018 & &
\end{tabular}

Analisis bivariat penelitian ini menunjukan bahwa sebanyak 17 responden $(42.5 \%)$ yang menggunakan kontrasepsi pil $\mathrm{KB}$ monofasik, terdapat 14 responden $(35.0 \%)$ yang mengalami perubahan siklus menstruasi polimenorea dan 3 responden $(7.5 \%)$ mengalami amenorea. Sedangkan sebanyak 23 responden yang menggunakan kontrasepsi pil $\mathrm{KB}$ trifasik, terdapat 16 responden $(40.0 \%)$ yang mengalami perubahan siklus menstruasi amenorea dan 7 responden (17.5\%) polimenorea. Berdasarkan hasil analisis dengan menggunakan uji chisquare memperoleh hasil 0.001 atau lebih kecil dari nilai $\alpha 0.05$ dengan kesimpulan bahwa terdapat hubungan yang bermakna antara penggunaan kontrasepsi pil $\mathrm{KB}$ dengan perubahan siklus menstruasi pada usia subur di Puskesmas Sonder dengan nilai odds ratio sebesar 10.667. Berdasarkan uji statistik dengan menggunakan Chi Square Test didapatkan $p$ value $=0,001<\alpha=0.05$, maka $\mathrm{H} 1$ diterima, berarti ada hubungan antara penggunaan kontrasepsi pil KB dengan perubahan siklus menstruasi di Puskesmas Sonder. Berdasarkan hasil penelitian ini peneliti berasumsi bahwa pemakaian kontrasepsi oral kombinasi dapat mempunyai efek samping terhadap 
perubahan siklus menstruasi, baik pemakaian kontrasepsi monofasik, maupun trifasik. Sehingga merupakan hal yang wajar jika resonden mengalami perubahan siklus menstruasi karena ketidaksesuaian dengan system hormon tubuh. (Baziad, 2008)

Hasil penelitian ditemukan bahwa adanya beberapa responden yang mengalami efek samping penggunaan kontrasepsi oral terhadap siklus menstruasinya dapat disebabkan karena pemakaiannnya tidak teratur, ketidaksesuaian antara hormon tubuh dengan hormon sintetis yang terkandung dalam kontrasepsi, misalnya pada sediaan kontrasepsi oral kombinasi monofasik, makin kecil dosis estrogen dan progesteron, makin sedikit pula darah yang keluar (oligomenorea bahkan amenorea) dan makin besar dosis estrogen dan progesteron, makin banyak pula darah yang keluar (polimenorea). Sedangkan pada sediaan trifasik dimana kadar estrogen makin meningkat dapat menyebabkan terjadinya perdarahan bercak (spotting). Sedangkan bagi ibu yang masih menyusui cenderung menggunakan minipil yang hanya mengandung progesteron. Namun penggunaan kontrasepsi oral yang teratur, sesuai dengan saran pemakaian ternyata cukup mampu membuat sebagian besar responden tidak mengalami perubahan siklus menstruasi. Hal ini disebabkan karena berbagai alat kontrasepsi dibuat dengan mempertimbangkan efek samping minimal. Selain itu tubuhnya mampu beradaptasi dengan hormon sintetis yang terkandung dalam kontrasepsi tersebut. (Hartanty, 2011).

Hasil penelitian ini sejalan dengan penelitian yang dilakukan oleh Faridah (2005) yang menyimpulkan bahwa ada hubungan yang bermakna antara pemakaian alat kontrasepsi pil dan suntik dengan gangguan menstruasi di Desa Gentan Kecamatan Susukan Kabupaten Serang. Hasil penelitian ini juga sama dengan hasil penelitian Tukiman (2012) yang menyatakan bahwa dari 42 orang pengguna pil $\mathrm{KB}$ sebanyak 38 orang $(90,5 \%)$ mengalami perubahan siklus menstruasi.

\section{SIMPULAN}

1. Sebagian besar responden menggunakan kontrasepsi pil KB trifasik yakni sebanyak 23 responden $(57.5 \%)$

2. Sebagian besar responden mengalami perubahan siklus menstruasi polimenorea yakni sebanyak 21 responden $(52.5 \%)$

3. Hasil analisis menunjukan terdapat hubungan antara penggunaan kontrasepsi pil KB dengan perubahan siklus menstruasi di Puskesmas Sonder dengan nilai signifikan 0.001 .

\section{DAFTAR PUSTAKA.}

Baziad, (2008). Endokrinologi Ginekologi. Edisi III. Jakarta: Media Aesculapius Fakultas Kedokteran Universitas Indonesia. Pg 35-36.

Dasharathy S. S, (2012). Menstrual bleeding patterns among regularly menstruating women. American Journal of Epidimiology, 175(6), 536545.

Faridah, 2005. Perbedaan Pola Menstruasi Antara Pemakaian Alat Kontra-sepsi Pil dan Suntik di Desa Gentan Kecamatan Susukan Kabupaten Serang. Skripsi tidak diterbitkan. Semarang: FKM UNDIP.

Hartani, 2011. Faktor-faktor yang mempengaruhi Ketidakpatuhan Akseptor Oral di Puskesmas Pajang Surakarta 
e-journal Keperawatan (eKp) Volume 7 Nomor 1, 11 Februari 2019

Manuaba, 2009. Memahami Kesehatan Reproduksi Wanita. Jakarta EGC

Nurlaila, 2015. Hubungan stress dan Siklus Menstruasi . Jurnal Husada Mahakam

Riset Kesehatan Dasar. (2010). Jakarta: Badan Penelitian dan Pengembangan Kesehatan Kementrian Kesehatan RI.

Sarwono, 2008 Gangguan Haid dan Siklusnya. Jakarta Bina Pustaka 2011

Sianipar, 2009. Prevelensi Gangguan Menstuasi dan faktor yang berhubungan pada siswi SMU pulo gadung. Majalah Kedokteran Indonesia

Sugiyono, 2011. Statistik Untuk Penelitian. Bandung : Alfabeta..

Suryoprajogo, 2008 Keajaiban Menyusui, Yogyakarta keyword

Siswosudarmo, (2007). Tegnologi Kontrasepsi. Yogyakarta: Gadjahmasa University Press

Tukiman, 2012. Hubungaan Penggunan Kontrasepsi Hormonal pada Kejadian Peningkatan Berat Badan di Puskesmas Tamanlarea Makassar

WHO, 2009. Kontrasepsi Hormonal. Tersedia Dalam: www.who.or.id [Diakses Tanggal 12 Maret 2017]

Wahyuni, 2013 Faktor-faktor yang Berhubungan dengan Penggunaan Alat Kontrasepsi Pil pada Akseptor KB kelurahan aur kuning . Jurnal kesehatan STIKES Prima Nusantara 
e-journal Keperawatan (eKp) Volume 7 Nomor 1, 11 Februari 2019 